\title{
POTENSI BAKTERI ASAM LAKTAT DALAM MENGHASILKAN BAKTERIOSIN SEBAGAI ANTIMIKROBA DAN PENGUKURAN BERAT MOLEKULNYA DENGAN SDS-PAGE DARI ISOLAT FERMENTASI KAKAO
}

\author{
Urnemi $^{*}$, Sumaryati Syukur ${ }^{1}$, Endang Purwati ${ }^{2}$, Sanusi Ibrahim ${ }^{3}$, Jamsari ${ }^{4}$, \\ *Program Doktor Jur. Kimia, Univ. Andalas Padang 25163 dan Lab. Bioteknologi Univ. \\ Mulawarman Kalimantan Timur \\ ${ }^{1}$ Lab. Bioteknologi Jur. Kimia, Fakultas Matematika Ilmu Pengetahuan Universitas Andalas \\ Padang Indonesia. 25163 \\ ${ }^{2}$ Lab. Bioteknologi Jur.Mikrobiologi Fak. Peternakan Universitas Andalas Padang Indonesia. 25163 \\ ${ }^{3}$ Lab.Kimia Organik, Jur. Kimia, University of Andalas Padang Indonesia. 25163 \\ ${ }^{4}$ Lab.Biotteknologi,Jur. Agronomi Fakultas Pertanian Univ. Andalas Padang Indonesia. 25163
}

\section{Email: urnemisyuib@ymail.com}

\begin{abstract}
Lactic acid bacteria (LAB) were isolated from of cocoa beans fermentation Forestero variety from West Sumatera, that were eleven isolates. The isolates were tested to antimicrobial activity against pathogenic bacteria E.coli NBRC 14237, Staphylococcus aureus NBRC 13276, Bacillus subtilis BTCCB 612, listeria $\mathrm{m}$. dan S. Typhii. Results the research showed that, isolates had inhibition zone to pathogenic bacteria, that were $7 \mathrm{~mm}$ till $12 \mathrm{~mm}$ at 48 hours observation. R2.4 isolate was most potential to inhibition zones growth pathogenic bacteria, that was $11 \mathrm{~mm}$ till $12 \mathrm{~mm}$ to five pathogens. R2.4 isolates was the highest to against pathogenic bacteria (Bacillus subtilis BTCCB, Listeria monocytogenesis and Staphylococcus aureus NBRC) had inhibition zones, that was 12.00 $\mathrm{mm}$ till 48 hours. Listeria monocytogenesis had been known as pest bacterium of food born, so that R2.4 isolate can be used as food biopreservative. Crude of R2.4 isolate molecular weight was 10 kDa by SDS-PAGE.
\end{abstract}

Key words: Lactic acid bacteria, Antimicrobial activity, SDS-PAGE, Cocoa fermentation and food biopreservative

\section{PENDAHULUAN}

Bakteri asam laktat (BAL) adalah bakteri yang dapat membantu proses fermentasi buah, sayuran, fermentasi daging, ikan. Fermentasi bertujuan untuk meningkatkan kualitas buah dan sayuran dan dapat juga membunuh bakteri patogen pada pada buah dan sayuran tersebut. Selain dapat membantu proses fermentasi, BAL juga dapat hidup di dalam saluran pencernaan manusia dan hewan. Pada saluran pencernaan, BAL berguna untuk membunuh/ menghambat pertumbuhan bakteri patogen. BAL didefinisikan sebagai bakteri pembentuk asam laktat dalam metabolisme karbohidrat, BAL mempunyai peranan penting dalam pengawetan bahan pangan dan melawan bakteri patogen melalui senyawa peptida antimikroba. BAL umumnya digunakan sebagai sterter untuk fermentasi daging dan sayuran, industri fermentasi saos, bahan flavor, dan juga berperan dalam perubahan aroma, warna, serta kualitas nutrisi produk fermentasi. BAL dikenal sebagai Food Grade Microorganism atau dikenal sebagai mikroorganisme yang Generally Recognized As Safe (GRAS), yaitu mikroorganisme yang tidak beresiko terhadap kesehatan dan bahkan berguna bagi kesehatan ${ }^{[1]}$.

BAL bisa bermanfaat sebagai pengawet makanan karena mampu memproduksi asam 
organik, menurunkan $\mathrm{pH}$ lingkungan dan mensekresikan senyawa yang mampu menghambat bakteri atau mikroorganisme patogen seperti $\mathrm{H}_{2} \mathrm{O}_{2}$, diasetil, $\mathrm{CO}_{2}$, asetaldehid, asam-asam amino dan bakteriosin. BAL tergolong ke dalam bakteri probiotik, karena melihat manfaat dan kandungan yang terdapat di dalamnya. Probiotik merupakan suplemen mikroba hidup yang memberikan efek positif kepada manusia atau hewan dengan memperbaiki mikroflora usus ${ }^{[2]}$.

Fermentasi pada biji kakao terjadi pada dua tahap, yaitu fermentasi anaerob dan fermentasi aerob. Keberadaan asam sitrat membuat lingkungan pulpa jadi asam, sehingga akan menginisiasi pertumbuhan ragi dan terjadi fermentasi secara anaerob. Fermentasi aerob diinisiasi oleh bakteri asam laktat (BAL) dan bakteri asam asetat. Pulpa pada kakao sebelum fermentasi mengandung air $72-79 \%$, garam 8 $10 \%$, pentosa $2-3 \%$, asam sitrat $1-2 \%$ dan sukrosa $10-13 \%$. Produk fermentasi yang dihasilkan berupa etanol, asam laktat, dan asam asetat yang berdifusi ke dalam biji dan membuat biji tidak berkecambah ${ }^{[3]}$.

Salah satu senyawa yang dihasilkan oleh BAL adalah bakteriosin. Bakteriosin merupakan senyawa protein yang dieksresikan oleh bakteri yang bersifat menghambat pertumbuhan bakteri lain terutama yang memiliki kekerabatan erat secara filogenetik. Bakteriosin mudah terdegradasi oleh enzim proteolitik dalam pencernaan manusia dan hewan. Penelitian tentang bakeriosin yang dihasilkan BAL semakin banyak berkembang, sehingga semakin banyak pula jenis bakteriosin baru yang ditemukan. Bakteriosin tersebut dapat digunakan sebagai antibiotik alami, karena memiliki kemampuan sebagai antibakteri patogen yang dapat menghancurkan sel-sel bakteri tersebut sehingga perkembangannya terganggu ${ }^{[4,5,6]}$.

Penelitian isolasi BAL dan bakteriosin telah banyak dilakukan, terutama pada produk fermentasi susu (yogurt, dadih, keju) ${ }^{[7]}$. Sebelumnya Fleet (2003) $)^{[3]}$ menyatakan bahwa pada buah-buahan, salah satunya adalah buah kakao berpotensi adanya BAL, melihat kandungan nutrisi pulpa buah kakao yang ada didalamnya, dengan parameter uji yaitu uji antimikroba tehadap pathogen ${ }^{[7]}$. Namun pada kakao varietas Forestero, 2 hari fermentasi dan uji berat molekul krud bakteriosin dengan menggunakan SDS-PAGE belum pernah dilaporkan.

Dari penelitian ini diharapkan bakteriosin yang dihasilkan dari LAB tersebut dapat digunakan sebagai bahan pengawet alami untuk bahan makanan seperti perikanan (susu, daging, telur, ikan dan udang) maupun produk olahan lainnya seperti keju, sosis dan baso.

\section{METODE PENELITIAN}

\section{Fermentasi pulpa biji kakao varietas Forestero}

Pulpa biji kakao dihomogenkan, Kemudian disediakan bak plastik yang ada tutupnya, alasi dengan daun pisang (layukan dulu diatas api, dan bersihkan) masukkan adonan pulpa biji kakao, taruh cabe diatasnya tutup dengan daun pisang, dan tutup plastik bak. Bungkus dengan kain, taruh ditempat yang aman (diatas lemari) selama 5 hari $^{[3]}$.

\section{Isolasi Bakteri Asam Laktat}

Bakteri asam laktat diisolasi dari fermentasi biji kakao varietas Forestero pada hari ke-dua fermentasi. 10 gm sampel ditambahkan dengan $90 \mathrm{ml}$ normal saline solution $(8,5 \mathrm{gm} \mathrm{NaCl} / \mathrm{L})$ divortek dan homogenkan selama 2 menit. Setelah itu dilakukan pengenceran sampai $10^{-7}$, kemudian diisolasi pada 2 cawan petri yang berisi media de Man Rogosa dan Sharpe agar (MRS agar), diinkubasi pada temperatur $37^{\circ} \mathrm{C}$ selama 24 jam di dalam incubator. Setelah tumbuh 11 singel koloni dimurnikan sebanyak 3 kali pemurnian disubkultur dalam MRS broth $^{[8,9]}$.

\section{Uji Aktivitas Antimikroba}

Uji aktivitas antimikroba dilakukan terhadap lima bakteri uji yaitu E.coli NBRC 14237, Staphylococcus aureus NBRC 13276, Bacillus 
subtilis BTCCB 612, listeria m. dan S. Typhii (Koleksi Laboratorium Bioteknologi Virologi LIPI. Cibinong Bogor). Metode yang digunakan adalah metoda difusi paper test steril assay ${ }^{[10]} .1 \mathrm{ml}$ kultur BAL disentrifugasi dengan kecepatan $6000 \mathrm{rpm}$ selama 5 menit pada suhu $4^{\circ} \mathrm{C}$, kemudian supernatannya digunakan untuk uji aktivitas antimikroba. Bakteri patogen yang akan diuji dimasukkan sebanyak $200 \mu \mathrm{l}$ ke dalam $20 \mathrm{ml}$ media nutrien agar (NA) yang masih cair, suhu berkisar antara $40^{\circ} \mathrm{C}$. Hasil campuran dihomogenkan, kemudian dituang ke dalam cawan petri steril. Dibiarkan selama 30 menit agar mengeras. Setelah media mengeras diteteskan $20 \mu \mathrm{l}$ supernatant BAL dengan mikropipet ke atas paper test steril tersebut, sebagai kontrol positif diberi Antibiotik testing paper yang telah steril dengan diameter $6 \mathrm{~mm}$, setelah itu diinkubasi pada suhu $37^{\circ} \mathrm{C}$ secara anaerob. Kemudian dilakukan pengamatan pada jam ke 3, 5, 8, 24 dan 48 terhadap zona hambat/zona bening, yang memperlihatkan zona bening disekitar paper test tersebut, disetiap jam pengamatan dilakukan pengukuran diameter zona hambat tersebut ${ }^{[11]}$.

\section{Karakterisasi Berat Molekul Bakteriosin dengan SDS-PAGE}

Tahapan karakterisasi Bakteriosin bakteri asam laktat R2.4 diawali dengan analisis bobot molekul peptida menggunakan elektroforesis $15 \%$ gel SDS poliakrilamid (SDS PAGE). Sampel dimasukkan sebanyak $20 \mu \mathrm{L}$ ke dalam sumur agar elektroforesis dengan marker pembanding (10-75 $\mathrm{kDa})$, yaitu 6 polypeptida digunakan sebagai marker. Setelah selesai elektroforesis SDS poliakrilamid, gel diwarnai dengan pewarnaan perak (silver stainning) Comassie Brilliant Blue R-250 hingga muncul pita-pita dioptimasi dengan menggunakan marker pembanding. Laemmli ${ }^{[12]}$ in LKB Bromma 2050 Midget electrophoresis units (Pharmacia Amersham Co).

\section{HASIL DAN PEMBAHASAN}

\section{Isolasi Bakteri Asam Laktat (BAL)}

Setelah dilakukan isolasi BAL pada pengenceran $10^{-7}$ didapatkan koloni BAL pada Gambar 1a. 11 isolat dilakukan pemurnian sebanyak tiga kali (Gambar 1b.), kemudian hasil pemurnian disimpan pada MRS broth dengan penambahan $15 \%$ glyserol pada $-70^{\circ} \mathrm{C}$. Kultur yang akan digunakan untuk uji selanjutnya disimpan dalam MRS broth pada $4^{0} \mathrm{C}$ dan disubkultur setiap interfal waktu 4 minggu. 11 isolat BAL tersebut diuji terhadap aktifitas antimikroba.

\section{Uji Aktifitas Antimikroba}

Hasil penelitain aktifitas antimikroba 11 isolat bakteri asam laktat yang diisolasi dari fermentasi 2 hari kakao varietas Forestero dapat dilihat pada Tabel 1.

Pada Tabel 1 menunjukan bahwa, diameter zona hambat dari 11 isolat BAL berfariasi antara $7 \mathrm{~mm}$ sampai $12 \mathrm{~mm}$. Isolat R2.4 memiliki zona hambat yang paling tinggi terhadap 5 bakteri patogen, yaitu $11 \mathrm{~mm}$ sampai $12 \mathrm{~mm}$. Isolat R2.4 ini paling potensial menghambat Listeria $m$, S.aureus NBRC 13276 (Gambar 2) dan S.thypii dengan diameter zona hambat $12 \mathrm{~mm}$ (Tabel1). Purwati (2003) ${ }^{[13]}$ menyatakan bahwa Listeria $m$ adalah bakteri patogen dominan pada pangan. Sebelumnya Leisner ${ }^{[8]}$ menyatakan bahwa BAL sebagai probiotik dapat melindungi makanan atau dapat membunuh bakteri patogen yang disebut (food preserfatif). Dengan demikian melihat daya hambat isolat R2.4 ini terhadap Listeria $m$, S.aureus NBRC 13276 dan S.thypii, isolat R2.4 boleh dikatan sebagai kandidat probiotik pada manusia, hewan dan pangan. 


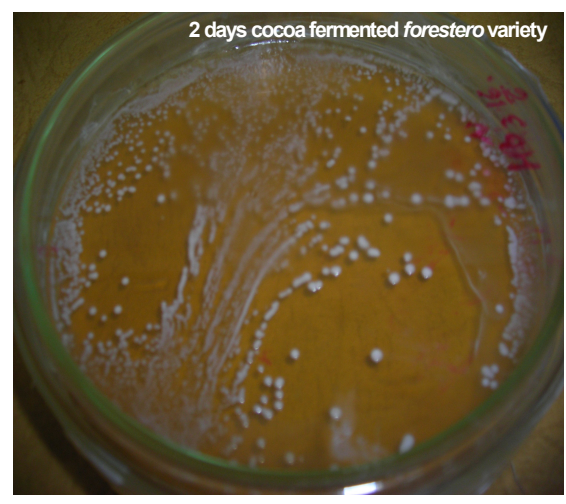

(a)

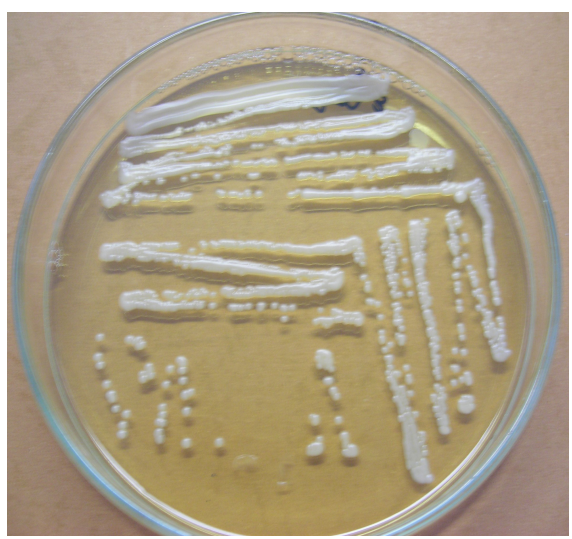

(b)

Gambar 1. Bakteri asam laktat pada MRS agar (Oxoid)

Keterangan: $\mathrm{a}=\mathrm{BAL}$ pada MRS agar (Oxoid)

$\mathrm{b}=$ BAL pemurnian tiga kali

Table 1: Aktifitas antimikroba 11 isolat bakteri asam laktat asal 2 hari fermentasi kakao varietas forestero pada media MRS agar dengan menggunakan uji paper diffusi assay 48 jam.

\begin{tabular}{lcccccc}
\hline Isolat & $\begin{array}{l}\text { Penicillin } \\
(+ \text { kontrol })\end{array}$ & $\begin{array}{c}\text { B.subtilis BTCCB } \\
\text { E.coli } \\
\text { NBRC } \\
\text { 14237 }\end{array}$ & $\begin{array}{c}\text { Listeria m. } \\
\text { S.aureus } \\
\text { NBRC } \\
13276\end{array}$ & S.thypii \\
\hline R2.1 & 9 & 9 & 7 & 9 & 8 & 8 \\
R2.2 & 9 & 9 & 9 & 8 & 10 & 10 \\
R2.3 & 9 & 10 & 10 & 11 & 10 & 10 \\
R2.4 & 9 & 11 & 11 & 12 & 12 & 12 \\
R2.5 & 9 & 9 & 9 & 9 & 9 & 9 \\
R2.6 & 9 & 9 & 9 & 9 & 10 & 10 \\
R2.7 & 9 & 10 & 9 & 10 & 10 & 9 \\
R2.8 & 9 & 9 & 9 & 10 & 10 & 10 \\
R2.9 & 9 & 9 & 10 & 9 & 10 & 9 \\
R2.10 & 8 & 10 & 10 & 10 & 10 & 10 \\
R2.11 & 8 & 10 & 10 & 8 & 9 & 10 \\
\hline
\end{tabular}



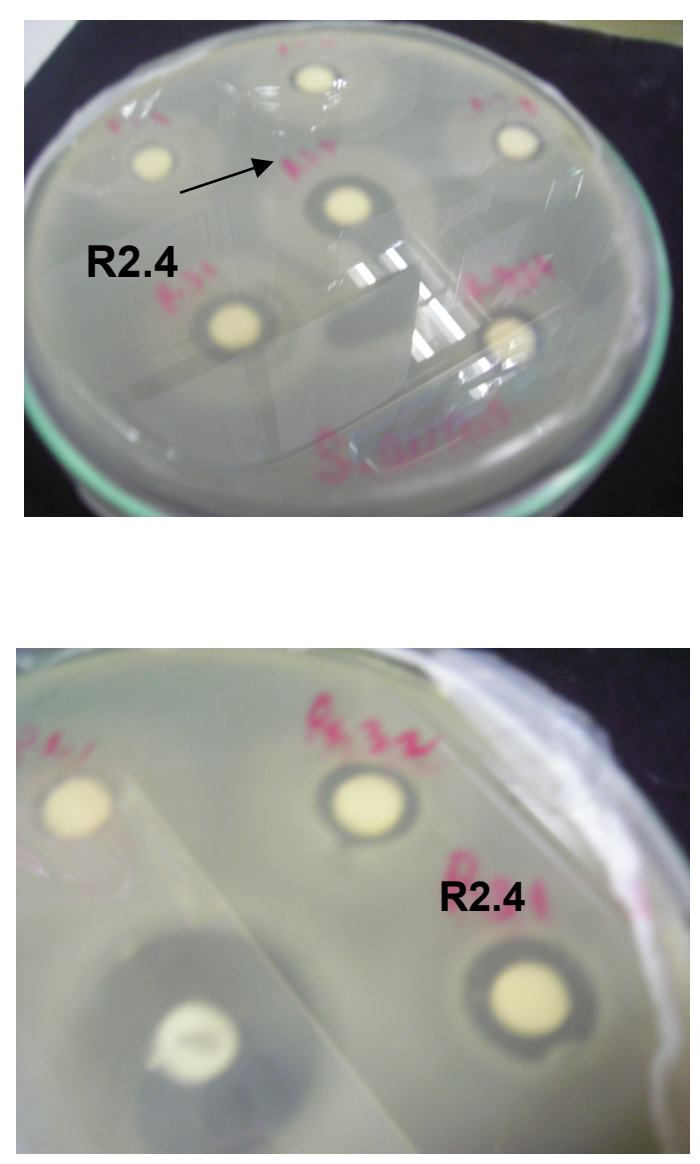

Gambar 2. Uji Aktifitas bakteri asam laktat terhadap bakteri patogen (S.aureus dan Listeria m.)

\section{Karakterisasi Berat Molekul Protein isolat R2.4 dengan SDS-PAGE}

Berat molekul protein isolat R2.4 dideterminasi dengan menggunakan SDSPAGE gel electrophoresis (Gambar 3), Pita yang ditunjukan setelah diberi pewarnaan stain Comassie blue menunjukan bahwa pada posisi $10 \mathrm{kDa}$. Untuk menghasilkan berat molekul protein R2.4 yang lebih murni, perlu dilakukan pemurnian bakteriosin melalui tahap pengendapan ammonium sulfat dan kolom kromatografi ion exchange ${ }^{[14]}$. Penelitain dari Kiran-kumar ${ }^{[14]}$ hasil pemurnian bakteriosin dari Pediococcus acidilactici asal fermentasi sayuran, di-dapatkan hasil berat molekul protein klass Iia, stabil terhadap panas, antilisterial berat molekol bacteriosin adalah $5 \mathrm{kDa}$. 


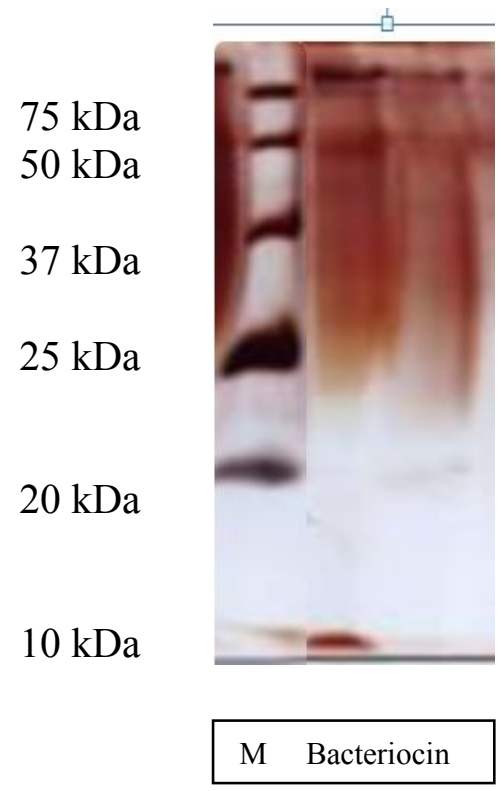

Gambar 3. SDS-PAGE dari Kultur krud isolat R2.4, Lane 1; molekular markers, lane 2; Berat molekul krud R2.4

\section{KESIMPULAN}

Isolat R24 adalah isolat berasal dari kakao fermentasi 2 hari varietas forestero dari Sumatera Barat. Isolat tersebut memiliki daya hambat yang tinggi terhadap bakteri pathogen Listeria m, S.aureus NBRC 13276 dan S.thypii dengan zona hambat $12 \mathrm{~mm}$ sampai 48 jam pengamatan. Isolat R2.4 memiliki berat molekul protein krud adalah $10 \mathrm{kDa}$ dengan menggunakan SDS-PAGE gel electrophoresis.

\section{UCAPAN TERIMA KASIH}

Penelitian ini didukung oleh sarana dan Prasarana laboratorium Biokimia Fakultas MIPA, Laboratorium Mikrobiologi Fakultas Peternakan, Laboratorium Bioteknologi Fakultas Pertanian Universitas Andalas Padang dan Laboratorium Bioteknologi dan virologi LIPI. Cibinong Bogor Indonesia, dan didanai oleh Hibah Disertasi Doktor, Kerja sama DIKTI dengan LEMBAGA PENELITAIN UNIVERSITAS ANDALAS Padang, NOMOR: 006/UN.16/PL/DD/V/2011.

\section{DAFTAR PUSTAKA}

1. L. Seppo, T. Jauhiainen, T. Poussa, and R. Korpela, A fermented milk high in bioactive peptides has a blood pressurelowering effect in hypertensive subjects. American Journal of Clinical Nutrition, 77, 326-330 (2004)

2. S. Taylor, Advances in Food and Nutrition Research, Vol. 50. Academic Press. ISBN 978-0-12-016450-9 (2004).

3. H.G. Fleet, The Microbial Ecology of Cocoa Bean Fermentation in Indonesia. Food Science and Technology School of Chemical Science University of New South Wales, Sidney. Australia (2003).

4. J. Serkedjieva, S. Danova, L. Ivanova, Antiinfluenza virus activity of a bacteriocin produced by Lactobacillus delbrueckii. Applied Biochemistry and Biotechnology 88: 285-298 (2000).

5. M.B. Wachsman, Enterococin CRL35 inhibits the last stage of HSV-1 and HSV2 replication in vitro. Antiviral Research 58: 17-24 (2003)

6. Todorov, An antibacterial and antiviral peptide produced by Enterococcus mundtii ST4V isolated from soya beans. 
Int. J. of Antimicrobial Agents 25: 508513 (2005).

7. S. Sumaryati dan E. Purwati, Peranan Pangan Probiotik Untuk Mikroba Patogen dan Kesehatan, Universitas Andalas Padang (2006).

8. J. J. Leisner, G. Rusul, B. W. Wee, H. C. Boo, and K. Mohammad, Microbiology of Chili Bo, A popular Malaysian food ingredient. Journal of Food Protection. 60:1235-1240 (1997).

9. De Man., J. C. Rogosa, M. E. Sharpe, A medium for the cultivation of lacto- bacilli. J. Appl.Bacteriol., 23, 130-135 (1960).

10. A. Mustopa, Colection Protocol Laboratorium Biotechnology and Virology Moleculer. Biotechnology Research Center. LIPI. Bogor (2007).
11. H. Holo, Nilssen, Nes IF, Lactococcin A, a new bacteriocin from Lactococcus lactis Subsp. cremoris: isolation and characterization of the protein and its gene. Journal of Bacteriology; 3879-87 (1991)

12. U.K. Laemmli, Cleavage of structural proteins during the assembly of the head of bacteriophage T4. Nature, 277: 680685 (1970.

13. E. Purwati, Molecular Chacarcterization of Listeria spp. Isolated from Beef, Chicken and Fermented Fish in Malaysia (2003).

14. Kiran-kumar, P.V. Badarinath, P.M. Halami, Isolation of anti-listerial bacteriocin producing Lactococcus lactis CFR-B3 from Beans (Phaseolus vulgaris). The Internet Journal of Microbiology. Volume 6 Number 1 (2009). 